\title{
CONFIRMATION OF ENDOPHYTIC MICROBES CAUSING CONTAMINATION IN WATER SPINACH (Ipomoea aquatica Forssk.) TISSUE CULTURE
}

\author{
Konfirmasi Mikroba Endofit Penyebab Kontaminasi pada Kultur Jaringan \\ Kangkung (Ipomoea aquatica Forssk.)
}

Resa Sri Rahayu*, Indriati Ramadhani, Masrukhin, Indira Riastiwi, Apriliana Dyah Prawestri, Yeni Yuliani Pusat Penelitian Biologi - Lembaga Ilmu Pengetahuan Indonesia, Cibinong Science Center, Jalan Raya Jakarta-Bogor Km. 46 Cibinong Jawa Barat 16911 Indonesia

*Email: resa.rahayu@gmail.com

\begin{abstract}
ABSTRAK
Tanaman kangkung secara alami bersimbiosis dengan mikroba endofit, yang berpotensi menjadi kontaminan pada kultur jaringan kangkung karena berada di dalam jaringan dan sulit dijangkau saat proses sterilisasi eksplan. Tujuan penelitian ini adalah mengonfirmasi mikroba endofit penyebab kontaminasi pada kultur jaringan kangkung 'Tetraploid' sehingga dapat menjadi informasi awal untuk metode sterilisasi yang efektif. Sebanyak 14 sampel kontaminan pada media tanam kultur jaringan kangkung diisolasi dan diidentifikasi secara molekuler berdasarkan gen 16S rDNA untuk bakteri, daerah D1/D2 dari gen LSU rRNA untuk khamir, dan daerah ITS dari gen rDNA untuk jamur. Keragaman jenis mikroba yang teridentifikasi dibandingkan dengan keragaman jenis mikroba endofit dari jaringan tanaman kangkung yang ditanam pada media kultur jaringan tidak terkontaminasi mikroba, media kultur jaringan terkontaminasi mikroba, media tanam campuran tanah steril dan tidak steril, serta kangkung yang didapatkan dari pasar. Hasil penelitian ini mengonfirmasi bahwa khamir endofit dari kelompok Ustilaginaceae (basidiomycetous yeast) yang berasal dari jaringan tanaman kangkung sama dengan jenis kontaminan yang mengontaminasi media kultur jaringan kangkung 'Tetraploid'. Khamir dari kelompok Ustilaginaceae (basidiomycetous yeast) tersebut juga merupakan mikroba paling dominan yang mengontaminasi media tanam kultur jaringan kangkung 'Tetraploid'.
\end{abstract}

Keywords: Ipomoea aquatica, kultur jaringan, mikroba endofit, morfologi, pohon filogeni

\begin{abstract}
Water spinach in nature lives in symbiosis with endophytic microbes, which have the potential to become contaminants in water spinach tissue culture because they are difficult to eliminate during the explant sterilization process. This study aimed to confirm endophytic microbes that cause contamination in the tissue culture of 'Tetraploid' water spinach so that it can provide initial information for an effective sterilization method. Fourteen contaminant samples in water spinach tissue culture media were isolated and identified molecularly based on the 16S rDNA gene for bacteria, the D1/D2 region of the LSU rRNA gene sequences for yeast, and ITS region of the rDNA gene for mold. The diversity of microbial species identified was compared with the diversity of endophytic microbial types from water spinach plant tissue grown on sterile tissue culture media, microbially contaminated tissue culture media, sterile and nonsterile soil mixed planting media, and water spinach obtained from the market. The results confirmed that endophytic yeast from Ustilaginaceae group (basidiomycetous yeast) derived from water spinach plant tissue was the same type of microbe that contaminated the 'Tetraploid' water spinach tissue culture media. The results gave new information that yeast from the Ustilaginaceae (basidiomycetous yeast) group was the most dominant microbe contaminating water spinach 'Tetraploid' tissue culture media. This group is endophytic yeast that lives within Ipomoea aquatica tissues.
\end{abstract}

Kata Kunci: endophytic microbes, Ipomoea aquatica, morphology, phylogenetic tree, tissue culture 


\section{INTRODUCTION}

Water spinach (Ipomoea aquatica Forssk.) is a kind of vegetable with various nutrients (Chitsa et al. 2014) so that it can be included in the daily diet as a functional food. Water spinach is also a vegetable crop that grows well in lowland to highland areas and has a short harvest age, hence easy to cultivate. 'Tetraploid' water spinach $(4 n=4 x$ = 60) (Rahmi et al. 2019) is a plant produced by polyploid induction (chromosome doubling) (Dhooghe et al. 2011) which has a greater biomass than diploid water spinach $(2 n=2 x=30)$, therefore it has larger cells as a result of chromosomes doubling. 'Tetraploid' water spinach with these advantages can increase the level of consumer preference for water spinach plants.

Endophytic microbes are microbes that live in plant tissue including water spinach plant tissue (Hapsari et al. 2014) and generally have a mutual symbiotic relationship with host plants (Wani et al. 2015), such as play crucial roles in plant development, growth, fitness, and diversification (Hardoim et al. 2015). Such kind of reports was developed further by researchers and found many benefits from the symbiosis of endophytic microbes, both fungi, bacteria, and yeast with various types of plants. These benefits include producing secondary metabolites as raw material for drugs (Panaccione et al. 2014, Shukla et al. 2014, Strobel 2018), producing IAA phytohormones (Sukmadi 2012), producing peptides as a plant defense against pathogens (Abdalla and Matasyoh 2014), increase plant tolerance to stress (Mei and Flinn 2010), clean environmental pollutants or bioremediation (Li et al. 2012, Stępniewska and Kuåniar 2013, Afzal et al. 2014, Arslan et al. 2017, Chen et al. 2017, Feng et al. 2017, Hussain et al. 2018), and assist in plant decomposition (Song et al. 2016). Endophytic microbes do not interfere with plant growth in ex vitro conditions but become constraints at in vitro planting conditions such as plant tissue culture because they cause contamination.

Propagation of water spinach seedlings through tissue culture techniques is one of the most effective and efficient propagation methods because it can produce mass water spinach plant seeds at one time aseptically so that the seeds produced are large, uniform, and free from pests and diseases. However, this propagation method is constrained by the high level of microbial contamination, both from within the plant tissue (endophyte) and the surface of the explant (Nair and Padmavathy 2014) as well as those brought from the environment at the time of explant initiation. Microbes on the surface of the explants and those carried from the environment at the culture initiation stage can be controlled by sterilizing media and explant sources. In contrast, endophytic microbes are difficult to control because they are inside the plant tissue (Hardoim et al. 2015). It is difficult to obtain pure tissue culture of water spinach plants because microbes such as bacteria, fungi, and yeast always grow around the water spinach tissue even it has been surface-sterilized. Therefore, this study aims to confirm the endophytic microbes that cause contamination in water spinach tissue culture as initial information for their control.

\section{MATERIALS AND METHODS}

\section{Research place and time}

The research was carried out at the Laboratory of Plant Cells and Tissues Culture, Botany Division, and Laboratory of Microbial Biosystematics and Evolution, Microbiology Division, Research Center for Biology - Indonesian Institute of Sciences (LIPI) from December 2019 to July 2020.

\section{Material}

The object of observation in this study was the microbes that contaminated the 'Tetraploid' water spinach tissue culture media (Rahmi et al. 2019), which would be compared with endophytic microbes in the water spinach plantlet tissue. Endophytic microbes with other water spinach plants were also isolated from comparing the types of endophytic microbes in water spinach plants. Details of the source of the endophytic microbial isolates of water spinach are listed in Table 1.

'Tetraploid' water spinach was grown in vitro on Murashige and Skoog (MS) media (Murashige and Skoog 1962). The shoots $( \pm 1$ $\mathrm{cm}$ ) of the 'Tetraploid' water spinach plantlets planted on sterile and contaminated media were used as materials for the isolation of 
endophytic microbes. Microbial colonies from contaminated media were also used as an isolation material for microbial contamination of the media. Water spinach 'Bangkok LP-1' plants were grown using conventional cultivation systems on mixed media of soil $(40 \%, w / w)$, roasted rice husk $(30 \%, w / w)$, and manure $(30 \%, w / w)$, and divided into two portions. One portion was then sterilized using an autoclave $\left(1.05 \mathrm{~kg} \mathrm{~cm}^{-2}\right.$ pressure for $20 \mathrm{~min}$ ) and one portion was not sterilized. About $1 \mathrm{~cm}$ of shoots of water spinach 'Bangkok LP-1', at one-week-old from both media, were taken for endophytic microbial isolation. Other water spinach plants are obtained from Cibinong Market in the Bogor Regency area (S 6 ${ }^{\circ} 37^{\prime} 58.932^{\prime \prime}, \mathrm{E} 106^{\circ} 51^{\prime}$ 23.832"). About $1 \mathrm{~cm}$ of the shoots of water spinach was taken for the isolation of endophytic microbes.

\section{Microbial isolation and purification}

Microbial isolation from contaminated water spinach tissue culture media was carried out aseptically in a laminar air-flow (LAF) cabinet. Microbial colonies on the media were taken and plated on potato dextrose agar (PDA) media + chloramphenicol antibiotics. The cultures were incubated at $27^{\circ} \mathrm{C}$ for 7 days. The emerging colonies were then transferred aseptically to a new culture medium for purification (Alexopoulos et al. 1996). Colonies that have been purified and have grown well were then selected and replanted in a test tube filled with PDA slant for two replications. The pure isolates that have grown were ready to be identified.

The endophytic microbial isolation from water spinach was carried out by washing samples and surface sterilization methods (llyas et al. 2006). The samples (stems and leaves) were surface-sterilized by soaking in sterile distilled water 2 times for 1 min each, followed by $70 \%$ ethanol for $1 \mathrm{~min}$, sterile distilled water for $2 \mathrm{~min}, 1 \%$ sodium hypochlorite $(\mathrm{NaOCl})$ for $30 \mathrm{~s}$, and rinsed with sterile distilled water 2 times for 1 min each. The samples were put on sterile tissue paper for 3 hours to drain water from the sample surface. The stem and leaf samples were transferred to malt extract agar (MEA) culture medium and incubated at room temperature $\left(25-27^{\circ} \mathrm{C}\right)$ for 7 days and observed daily.
Microbes that grow on the sample were selected to be isolated and purified to PDA.

\section{DNA extraction, amplification, and sequencing}

Yeast DNA extraction using lysis buffer (20 mM Tris-HCl; 5 mM EDTA; 400 mM NaCl; $0.3 \%$ SDS) and through heating at $98^{\circ} \mathrm{C}$. Amplification of the D1/D2 LSU rDNA region in the PCR reaction using primers NL1 (5' CAT ATC AAT AAG CGA AAA G-3') and NL4 (5'-GGT CCG TGT TTC AAG ACG G3') (Kurtzman and Robnett 1998). PCR reaction conditions are at $95^{\circ} \mathrm{C}$ for initial denaturation followed by 30 reaction cycles (denaturation at $95^{\circ} \mathrm{C}$ for $30 \mathrm{~s}$, annealing at $55^{\circ} \mathrm{C}$ for $30 \mathrm{~s}$, and elongation at $72^{\circ} \mathrm{C}$ for 60 $\mathrm{s}$, followed by final elongation at $72^{\circ} \mathrm{C}$ for 5 min. Electrophoresis using 1.2\% agarose gel (100 V for $20 \mathrm{~min}$ ) on ethidium bromide (EtBr), then documented using a Gel Doc ${ }^{\mathrm{TM}} \mathrm{EZ}$ Gel imager (Bio-Rad, USA). The $1 \mathrm{~Kb}$ DNA ladder was used as a marker.

Fungal DNA extraction was performed using the Nucleon Phytopure ${ }^{\mathrm{TM}}$ Plant DNA Extraction Kit (Amersham Life Sciences, Buckinghamshire, UK). PCR amplification was carried out in the ITS area (ITS1, 5.8S, and ITS2 rDNA) using the primer pairs ITS4 (5'-TCC TCC GCT TAT TGA TGC-3') and ITS5 (5'-GGA AGT AAA AGT CGT AAC AAG G-3' ) (White et al. 1990). PCR amplification was performed using programmed Arctic Thermal Cycler PCR (Thermo Fisher Scientific Oy, Vantaa, Finland) with flow condensation: denaturation at $95^{\circ} \mathrm{C}$ for $3 \mathrm{~min}$, repeated 35 cycles of strand DNA opening at $95^{\circ} \mathrm{C}$ for $30 \mathrm{~s}$, annealing at $55^{\circ} \mathrm{C}$ for $30 \mathrm{~s}$, and primary elongation at $72^{\circ} \mathrm{C}$ for $1 \mathrm{~min}$. PCR results were visualized on electrophoresis using $1.2 \%$ agarose gel ( $100 \mathrm{~V}$ for $20 \mathrm{~min}$ ) on ethidium bromide (EtBr), then documented using a Gel Doc ${ }^{T M}$ EZ Gel imager (Bio-Rad, USA). The $1 \mathrm{~Kb}$ DNA ladder was used as a marker.

Bacterial identification was conducted using a molecular approach based on 16S rDNA gene. Total bacterial DNA was extracted from a pure bacterial colony using the boiling method. One colony of bacteria was taken and suspended into $100 \mu \mathrm{L}$ of sterile distillate water and boiled at $95^{\circ} \mathrm{C}$ for $10 \mathrm{~min}$. The suspension was then precipitated using DNA spin for 2 min. Amplification of $16 \mathrm{~S}$ rDNA gene was performed using universal 
primer 27f $\left(5^{\prime}-\right.$ AGA GTT TGG ATC MTG GCT CAG-3) and 1492r (5-CGG TTA CCT TGT TAC GAC TT-3') primer pair (Jiang et al. 2006). The PCR products were then visualized using agarose electrophoresis. The positive results were shown in a single DNA band.

\section{Morphological analysis of isolates}

The identification of yeast and fungal morphology was carried out by observing the morphological characters both macroscopically and microscopically. Macroscopic characters observed were color, form, elevation, margin, texture, mycelia, opacity, and increasing diameter per day $(\mathrm{mm})$ and the microscopic characters observed were the presence or absence of septa in hyphae, hyphae pigmentation, the shape and ornamentation of spores, and others. Microscopic observation and documentation were performed using a compound microscope (Olympus BX53, Japan).

The identification of bacterial morphology was carried out by using Gram staining and observing the shape of the cells. Gram staining was performed using the Gram staining kit (Himedia Lab). The staining kit consists of several dyes, including crystal violet dye, Gram's iodine gram, Gram's decolorizer, and $0.5 \%$ safranin. The staining procedure follows the protocol provided by the manufacturer. The stained bacterial cell was then observed with a compound microscope (Olympus BX53, Japan).

\section{Phylogenetic analysis}

DNA sequencing was carried out at Macrogen Inc. (Macrogen, Seoul, Korea) using the Sanger method (Sanger et al. 1977) and screening using the $\mathrm{ABI} 3370 \mathrm{xl}$ DNA Analyzer (Applied Biosystems, US). Analysis of the new nucleotide sequences of fungi and bacteria with closely related sequences were obtained from the NCBI GenBank database using BLAST (https://www.ncbi.nlm.nih.gov/BLAST/). The sequences were assembled using MAFFT version 7 (Katoh et al. 2019) and refined with MEGA 7.0 software (Kumar et al. 2016). The phylogenetic trees were conducted with MEGA 7.0 and iTOL (https://itol.embl.de). The Neighbor-Joining (NJ) method (Saitou and Nei 1987) was obtained from the dataset using the Kimura 2-parameter $+\mathrm{G}+\mathrm{I}$ model as the best evolutionary model for the dataset (Kimura 1980). Clade robustness was assessed using bootstrap (BS) analysis with 1000 replicates (Felsenstein 1985).

\section{RESULT AND DISCUSSION}

This study identified the microbial diversity of 14 contaminant samples on the growing media for 'Tetraploid' water spinach tissue culture which were visually different and endophytic microbes isolated from water spinach from five different conditions (Table 1 ). The results showed that the diversity of microbes that contaminated 14 samples of 'Tetraploid' water spinach tissue culture media consisted of yeast, fungi, and bacteria. Colonies of one type of yeast, fungi, and bacteria that contaminate the 'Tetraploid' water spinach tissue culture media are shown in Figure 1 and pure isolates from the 14 contamination samples are shown in Figure 2. Endophytic microbial diversity in plant tissue water spinach derived from five different conditions mentioned in Table 1 consists of yeast and fungi and pure isolates are shown in Figure 5.

\section{Diversity of microbes in tissue culture media}

A total of 14 microbial isolates consisting of bacteria $(68.75 \%)$, yeast $(12.50 \%)$, and fungi (18.75\%) were isolated from 14 contaminant samples of 'Tetraploid' water spinach tissue culture media (Figure 3). The results of the comparative analysis of sequences from NCBI GenBank showed several genera classified as bacteria, including Luteibacter (1 species), Curtobacterium (2 species), Xanthomonas (1 species), and Caballeronia (1 species). Moreover, several genera classified as fungi including Cladosporium (2 species) and Aspergillus (1 species), and the genus belonging to the yeast, namely Moesziomyces (1 species). These five fungal strains are distributed into three families, namely Ustilaginaceae, Cladosporiaceae, and Aspergillaceae.

Phylogenetic analysis showed that the most dominant endophytic bacterial isolates found were part of the Actinobacteria class, followed by Gammaproteobacteria and Betaproteobacteria (Table 2 and Figure 4). Most of the Actinobacteria isolated were of 
Table 1. Sources of endophytic microbial isolates of water spinach plants used in this study

\begin{tabular}{clc}
\hline No. & Types of Water Spinach Plants & Original Conditions \\
\hline 1 & Salina 'Tetraploid' & Planted in tissue culture media not contaminated with microbes \\
2 & Salina 'Tetraploid' & Planted in tissue culture media contaminated with microbes \\
3 & Bangkok LP-1 & Planted in a sterile soil mixture \\
4 & Bangkok LP-1 & Planted in an unsterile soil mixture \\
5 & Unknown (cultivated by farmers) & Market \\
\hline
\end{tabular}
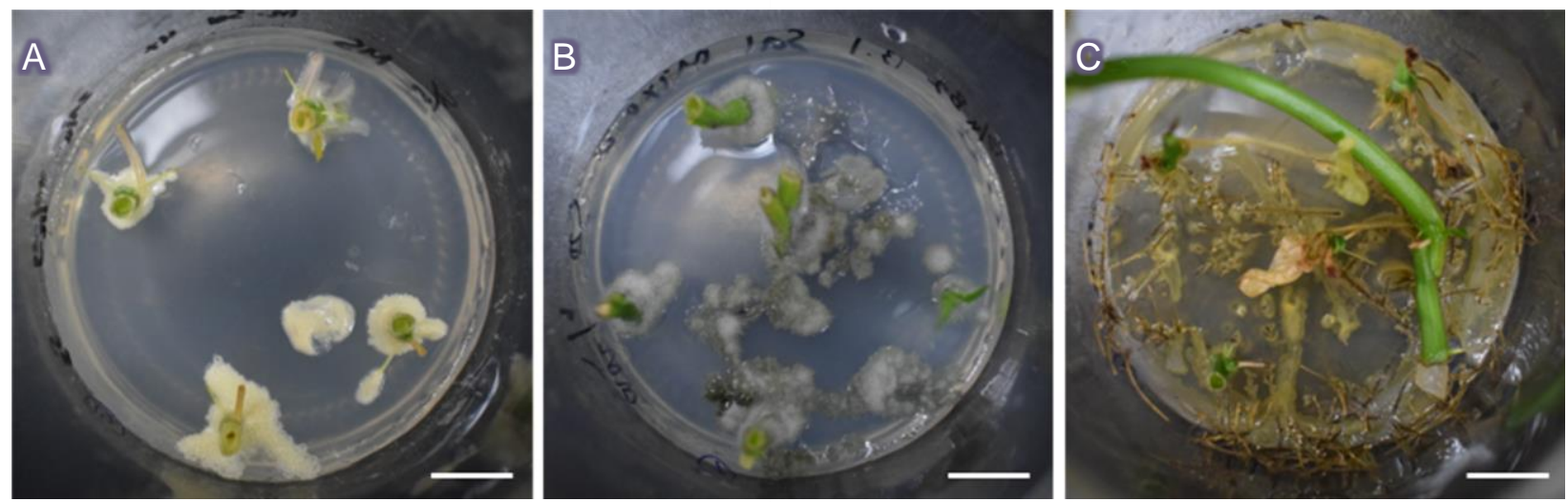

Figure 1. Microbial contamination on tissue culture media of 'Tetraploid' water spinach. Colonies of yeast (A), fungi (B), and bacteria (C) on 'Tetraploid' water spinach tissue culture media. Scale bars $=1 \mathrm{~cm}$.

Table 2. Results of molecular identification of microbes that contaminate the growing medium of 'Tetraploid' water spinach tissue culture

\begin{tabular}{ccc}
\hline Isolate Code & Isolate Identity & \% Similarity \\
\hline CK20-B-01 & Luteibacter sp. & 99.66 \\
CK20-B-02 & Luteibacter rhizovicinus & 99.49 \\
CK20-B-03 & Curtobacterium luteum & 99.85 \\
CK20-B-04 & Curtobacterium citreum & 99.70 \\
CK20-B-05 & Xanthomonas campestris & 100.00 \\
CK20-B-06 & Curtobacterium luteum & 99.40 \\
CK20-F-01 & Cladosporium tenuissimum & 99.63 \\
CK20-B-07 & Curtobacterium luteum & 99.40 \\
CK20-Y-01 & Moesziomyces parantarcticus & 99.04 \\
CK20-F-02 & Aspergillus versicolor & 98.58 \\
CK20-F-03 & Cladosporium halotolerans & 99.09 \\
CK20-B-08 & Curtobacterium luteum & 99.73 \\
CK20-B-09 & Curtobacterium luteum & 99.78 \\
CK20-Y-02 & Moesziomyces parantarcticus & 99.04 \\
\hline
\end{tabular}

the genus Curtobacterium. Several studies have shown that Curtobacterium is an endophytic bacterium with a wide host range. Curtobacterium luteum was found to be endophytic bacteria in food crops such as potatoes and corn (de Pereira et al. 2012, Liu et al. 2012) as well as fruit crops such as strawberries and rambutan (de Pereira et al. 2012, Suhandono et al. 2016). The most dominant species of the fungal group is Moesziomyces parantarcticus. The results of this study are the same as previous studies which showed that the genus Moesziomyces (Ustilaginomycotina) is one of the endophytic Basidiomycetous yeast species in rice, corn, and sugarcane plants in Thailand (Khunnamwong et al. 2018, Srisuk et al. 2019, Into et al. 2020). 
Table 3. Results of microbes molecular identification of endophytic microbial isolates of water spinach

\begin{tabular}{ccc}
\hline Isolate Code & Isolate Identity & $\%$ Similarity \\
\hline EK20-F-01 & Schizophyllum commune & 100.00 \\
EK20-F-02 & Peroneutypa scoparia & 99.83 \\
EK20-F-03 & Pyricularia urashimae & 100.00 \\
EK20-Y-01 & Dirkmeia churashimaensis & 100.00 \\
EK20-Y-02 & Dirkmeia churashimaensis & 100.00 \\
EK20-Y-03 & Dirkmeia churashimaensis & 100.00 \\
EK20-Y-04 & Dirkmeia churashimaensis & 100.00 \\
EK20-F-04 & Epicoccum sorghinum & 100.00 \\
\hline
\end{tabular}

\section{Diversity of the endophytic microbes}

A total of eight pure microbial isolates consisting of yeast (50\%) and fungi $(50 \%)$ were isolated from water spinach plant tissue from five different conditions as mentioned in Table 1 and Figure 6. Some genera were classified as fungi including Schizophyllum, Peroneutypa, and Epicoccum. The genus classified as yeast was Dirkmeia. Our result showed that the most dominant endophytic microbial species in water spinach was Dirkmeia churashimaensis (Table 3). The same results were also reported by (Khunnamwong et al. 2018) that $D$. churashimaensis were the most prevalent known Basidiomycetous yeast species detected in rice and corn leaf tissue.

The results in Figure 6 show that there are three types of endophytic microbes from the fungi that were isolated from water spinach plant tissue even though they were planted on sterile media (plant conditions 1 and 3 in Table 1). This can be presumed because the three endophytes are classified as seed-borne endophytes or seed endophytes (Shahzad et al. 2018). Seeds are a fundamental part of a spermatophyte life cycle, hence they have a high possibility of containing endophytic microbes in them from the parent plant (López et al. 2018). Some of the plants reported having seed endophytes are hybrid tomatoes (López et al. 2018), and Brassica oleracea (Tyc et al. 2020).

The endophytic microbes that were found in sterile in vitro water spinach plant tissue (plant condition 1 in Table 1) are a group of endophytic fungi, namely $S$. commune (Figure 6a, isolate EK20-F-01). This endophytic fungus has high potential as a natural insecticide in killing pests, especially the insects Spodoptera litura, a type of moth, by inducing genotoxic and cytotoxic effects. This fungus extract which is eaten by $S$. litura will increase oxidative stress which results in significant damage to the DNA of $S$. litura cells, thereby increasing the frequency of cells experiencing apoptosis and necrosis. In addition, extracts of the fungus $S$. commune can cause the death of haemocytes (blood cells in insects), thereby reducing the frequency of living haemocytes (Kaur et al. 2018). This is very beneficial for increasing the survival of water spinach plants planted in open environments because they can be protected from insect pests, especially $S$. litura. S. commune has also been reported to produce diketopiperazines, aryl-ethyl amides, and $p$ hydroxybenzoic acid, a class of compounds that have high antioxidant and antifungal activity. Therefore, indirectly, S. commune contained in plant tissue can play a role in plant protection as a defense mechanism against microbes that can inhibit plant growth (Biasetto et al. 2019).

Peroneutypa scoparia was found in the tissue of water spinach plants grown on sterile soil mixed media (plant conditions 3 in Table 1 ). This type of fungus has low host specificity. This species is saprophytic, acts as a degrading agent which has a high ability in the process of rotting wood. However, $P$. scoparia is also an endophytic fungus found in living plant tissue and is not pathogenic (de Errasti et al. 2014). Therefore, P. scoparia will not interfere with plant growth while the plant is still alive.

Epicoccum sorghinum found in water spinach plant tissue obtained from the market (plant conditions 5 in Table 1) is a facultative fungal pathogen that generally causes fungal rot disease in wheat germ which produces tenuazonic acid mycotoxin (Oliveira et al. 2017) and root rot disease 
which causes stunted growth of wheat plants (Stokholm et al. 2016). E. sorghinum is also the cause of dragon fruit spotting (Taguiam et al. 2020). On the other hand, this endophytic fungus is also capable of producing $\mathrm{N}$-methoxypyridone compounds which are antimicrobial against other pathogenic microbes and anti-proliferation against ovarian cancer cells (Li et al. 2017). This is interesting because in Treatment 3, water spinach did not experience root rot and spot; therefore, this endophyte might not be pathogenic to water spinach. It did not inhibit the growth of water spinach.

Research on the diversity of endophytic microbes in water spinach is still limited. Reports on the diversity of endophytic fungi showed that there are 18 genera of endophytic fungi isolated from roots (Hapsari et al. 2014) and 11 genera of endophytic fungi
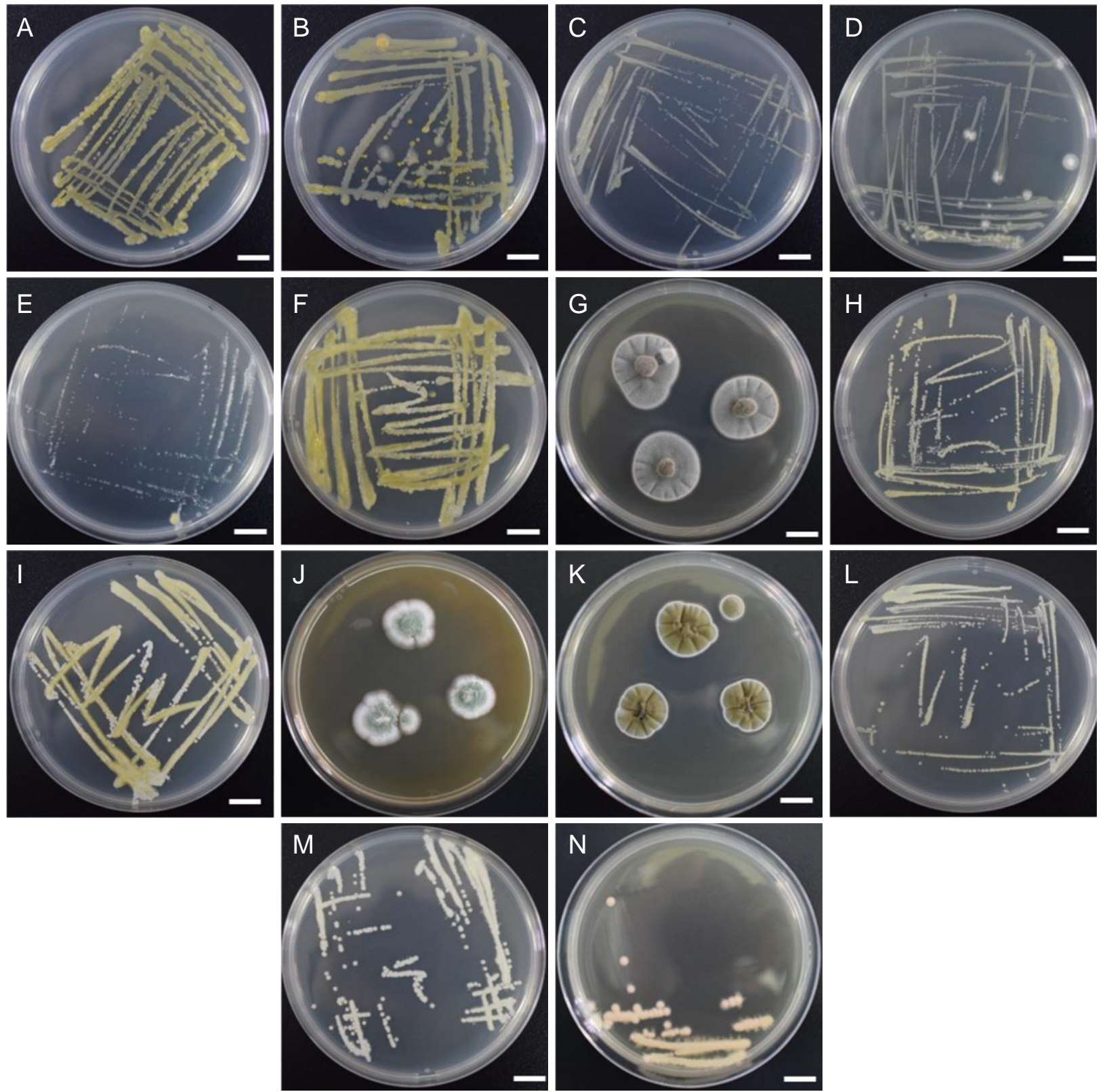

Figure 2. Microbial isolates obtained from culture media of water spinach 'Tetraploid' after 7 days of incubation. A) bacteria Luteibacter sp. (CK20-B-01); B) bacteria Luteibacter rhizovicinus (CK20-B-02); C) bacteria Curtobacterium luteum (CK20-B-03); D) bacteria Curtobacterium citreum (CK20-B-04); E) bacteria Xanthomonas campestris (CK20-B-05); F) bacteria Curtobacterium luteum (CK20-B-06); G) fungi Cladosporium tenuissimum (CK20-F-01); H) bacteria Curtobacterium luteum (CK20-B-07); I) yeast Moesziomyces parantarcticus (CK20-Y-01); J) fungi Aspergillus versicolor CK20-F-02); K) fungi Cladosporium halotolerans (CK20-F-03); L) bacteria Curtobacterium luteum (CK20-B-08); M) bacteria Curtobacterium luteum (CK20-B-09); N) yeast Moesziomyces parantarcticus (CK20-Y-02). Scale bars: $1 \mathrm{~cm}$ 
isolated from leaves (Ariyono et al. 2014) of terrestrial water spinach (I. reptans) from organic and conventional agriculture in Malang City. All these endophytic fungi were different from the endophytic fungi reported in this paper. It is suspected that the different locations of water spinach cultivation affect the diversity of endophytic microbes in water spinach plant tissue. This is in line with the results of research by Chauhan et al. (2019) who reported that there were differences in the number of endophytic fungi isolated from three different agroecosystem areas.

\section{Comparison of the microbes}

Based on the results of molecular identification, there were microbes from the growing media of 'Tetraploid' water spinach
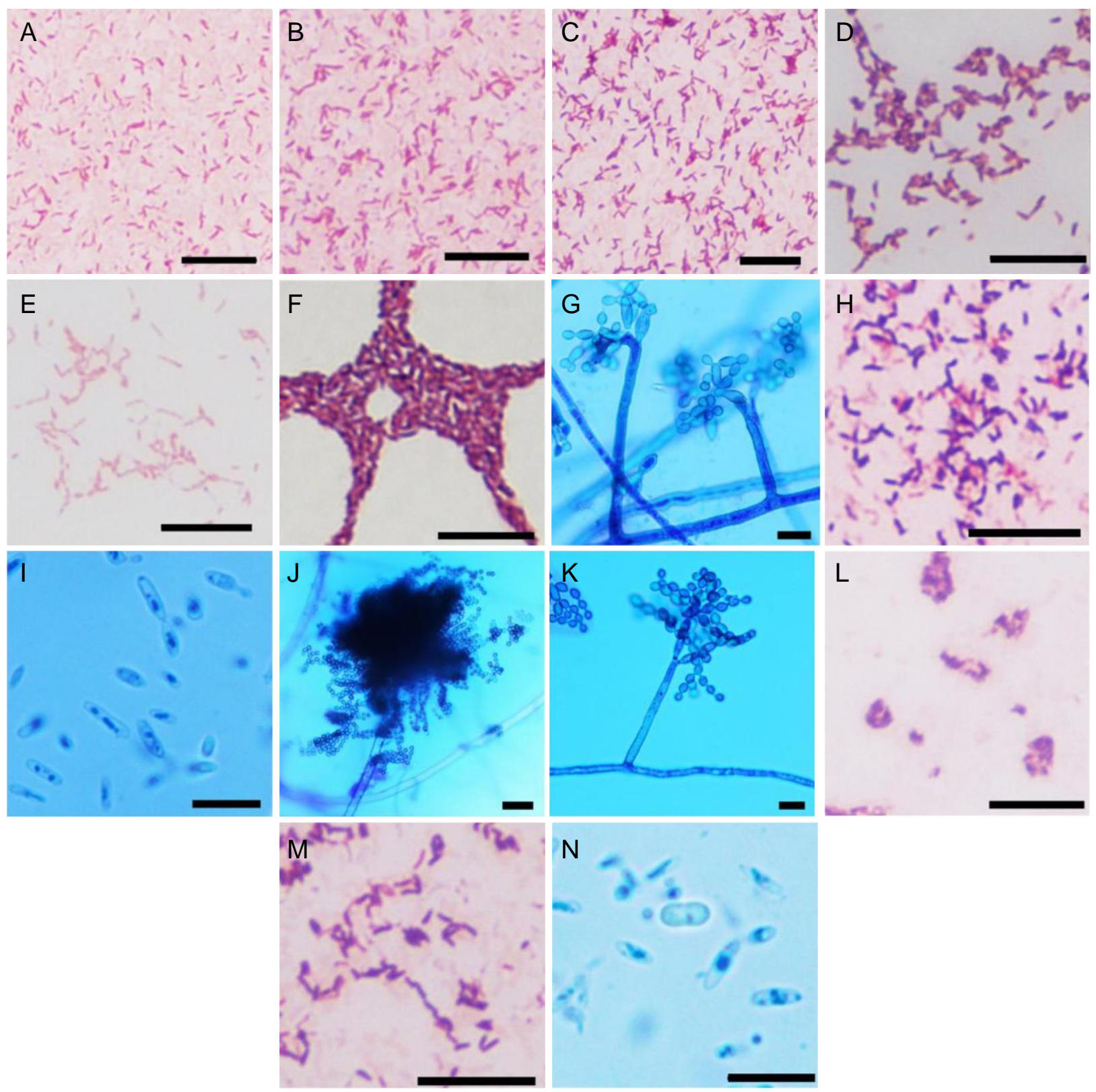

Figure 3. Microscopic characteristics of microbes that contaminate the growing medium of 'Tetraploid' water spinach tissue culture after 7 days of incubation. A) bacteria Luteibacter sp. (CK20-B-01); B) bacteria Luteibacter rhizovicinus (CK20-B-02); C) bacteria Curtobacterium luteum (CK20-B-03); D) bacteria Curtobacterium citreum (CK20-B-04); E) bacteria Xanthomonas campestriss (CK20-B-05); F) bacteria Curtobacterium luteum (CK20-B-06); G) fungi Cladosporium tenuissimum (CK20-F-01); H) bacteria Curtobacterium luteum (CK20-B-07); I) yeast Moesziomyces parantarcticus (CK20-Y-01); J) fungi Aspergillus versicolor (CK20-F02); K) fungi Cladosporium halotolerans (CK20-F-03); L) bacteria Curtobacterium luteum (CK20-B-08); M) bacteria Curtobacterium luteum (CK20-B-09); N) yeast Moesziomyces parantarcticus (CK20-Y-02). Scale bars: A-F, H-I, M-N: $10 \mu \mathrm{m}$; and G, J, K: $20 \mu \mathrm{m}$ 
tissue culture and endophytic microbes of water spinach tissue from the same family, namely Ustilaginaceae (Basidiomycetous yeast) and included in the genus Moesziomyces and Dirkmeia (Figure 7). Both genera were also found in the rice and corn leaves tissue. The basidiomycetous yeasts in the Ustilaginaceae were the most prevalent endophytic yeast in rice and corn leaves (Khunnamwong et al. 2018). Basidiomycetous yeasts are mostly found in specialized niches, are a low concentration of carbon compounds (Suh et al. 2006). This is supported by Saad et al. (2020) who reported that kale can grow on soil contaminated by heavy metals such as $\mathrm{Pb}, \mathrm{Cd}$, and $\mathrm{Zn}$. Therefore, kale can be used as phytoremediation.
The results of this study indicated that the microbes that were isolated from tissue culture media of 'Tetraploid' water spinach and endophytic microbes came from the same family, namely Ustilaginaceae (Basidiomycetous yeast), but with a different genus. The difference in the genus might be caused by differences in the age of water spinach plants which were a source of contaminants in the tissue culture media and endophytic microbes from water spinach plant tissues originating from different conditions were randomly collected so that they might not be in the same age when sampled. This affects the presence of yeast in plant tissue as stated by Jumpponen and Jones (2010) that the distribution of yeast

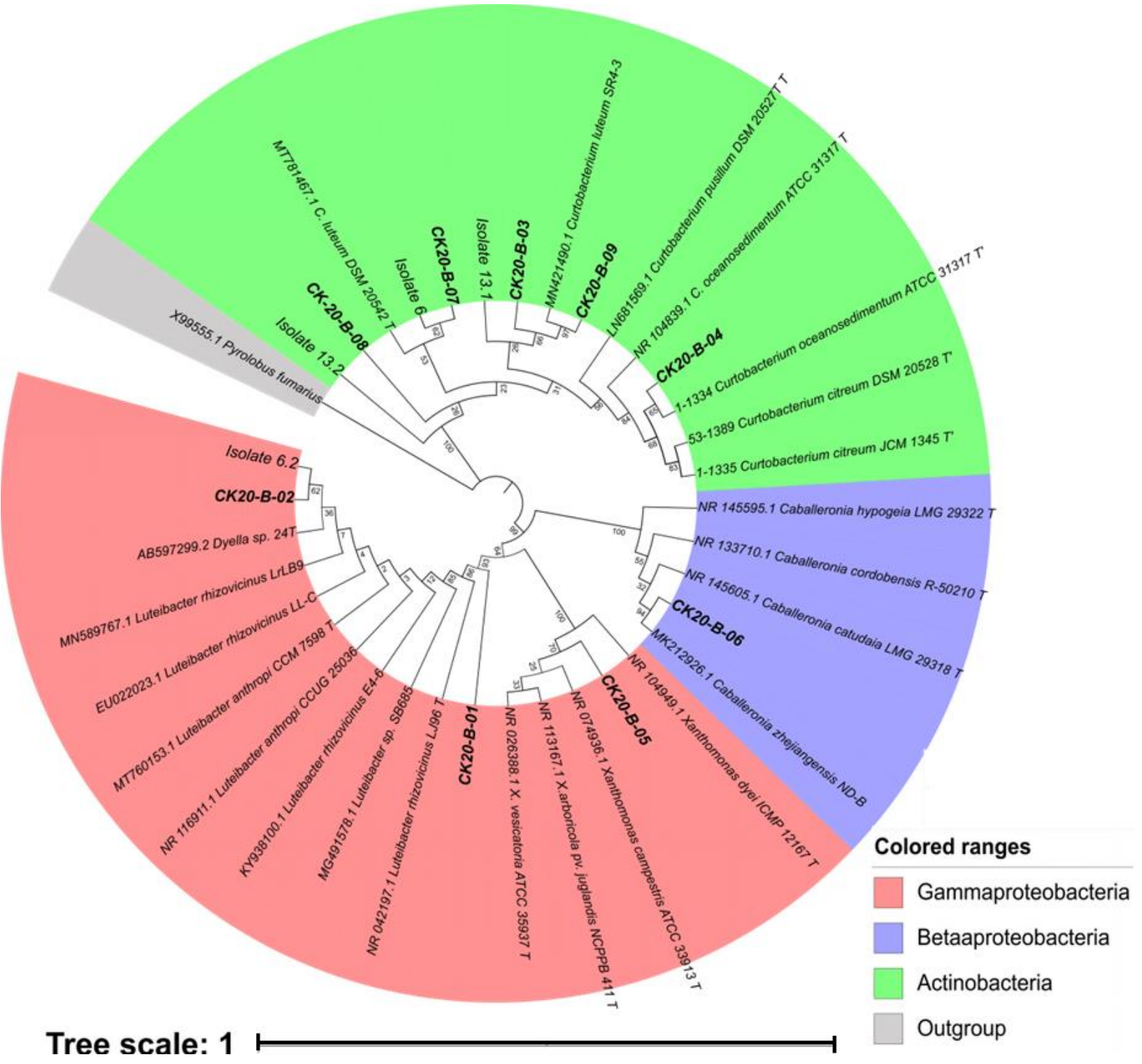

Figure 4. Phylogenetic tree of bacterial isolates on the growing media for 'Tetraploid' water spinach tissue culture was calculated using the neighbor-joining method with 1000x bootstrap. The suffix "T" at the end of the strain name indicates the strain type 
species in plant tissue is influenced by plant age. Another study by Wagner et al. (2016) also showed that microbial composition on leaves and roots of Brassicaceae shifts as the plants age.
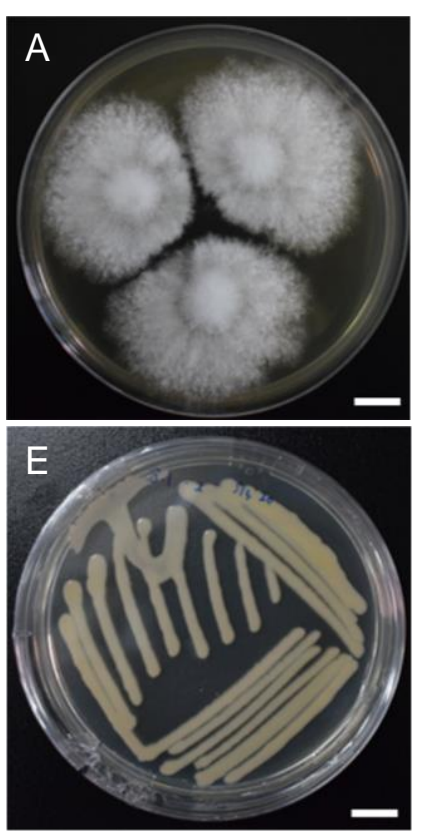
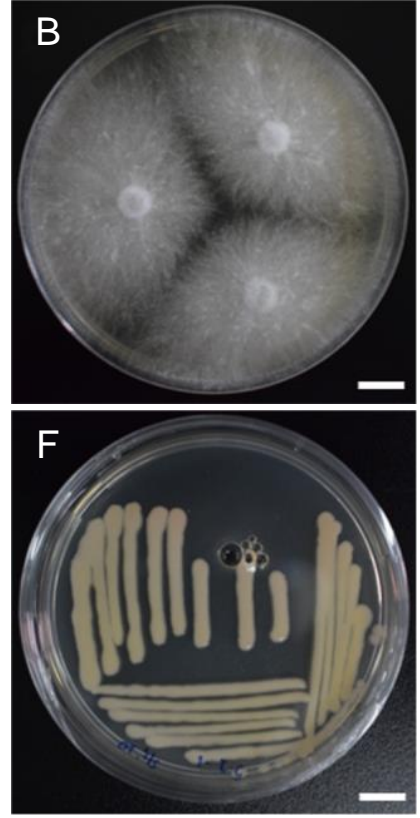

Based on the phylogenetic tree generated from the $\mathrm{NJ}$ analysis, two sequences of Ustilagineous yeasts (CK20-Y01 and CK20-Y-02) isolated from tissue culture media of 'Tetraploid' water spinach

Figure 5. Endophytic microbial isolates of water spinach from various plant conditions after 7 days of incubation. A) EK20F-01= Endophyte from Salina 'Tetraploid' water spinach tissue that planted in tissue culture media not contaminated with microbes (fungi Schizophyllum commune); B) EK20-F-02 - EK20-F-03= endophyte from 'Bangkok LP-1' water spinach tissue that planted in a sterile soil mixture (EK20-F-02= fungi Peroneutypa scoparia; C) EK20-F-03= fungi Pyricularia urashimae); D-E) EK20-Y-01 - EK20-F-04= endophyte from water spinach tissue obtained from market (EK20-Y-01= yeast Dirkmeia churashimaensis; EK20-Y-02=yeast Dirkmeia churashimaensis; F) EK20-Y-03= yeast Dirkmeia churashimaensis; G) EK20-Y-04= yeast Dirkmeia churashimaensis; H) EK20-F-04= fungi Epicoccum sorghinum). Scale bars: $1 \mathrm{~cm}$
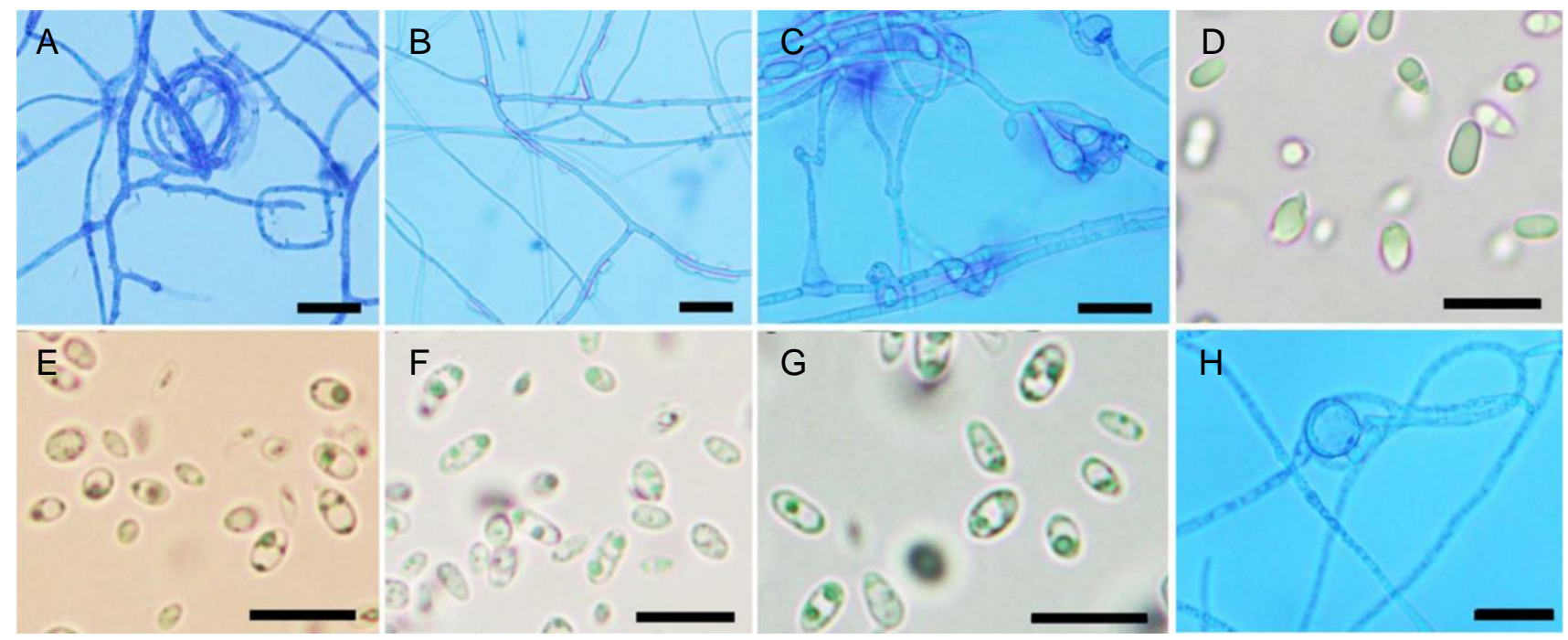

Figure 6. Microscopic of endophytic microbial isolates of water spinach from various plant conditions after 7 days of incubation. A) endophyte from sterile Salina 'Tetraploid' water spinach tissue planted in tissue culture media (Isolate EK20-F-01 = fungi Schizophyllum commune); B-C) endophyte from 'Bangkok LP-1' water spinach tissue planted in a sterile soil mixture (Isolate EK20-F-02 = fungi Peroneutypa scoparia (B); isolate EK20-F-03= fungi Pyricularia urashimae (C)); D-H) endophyte from water spinach tissue obtained from Cibinong market (Isolate EK20-Y-01, EK20-Y-02, EK20-Y-03, EK20-Y-04= yeast Dirkmeia churashimaensis (D-G); Isolate EK20-F-04= fungi Epicoccum sorghinum (h)). Scale bars: A-C, H: $10 \mu \mathrm{m}$; D-G: $20 \mu \mathrm{m}$ 
nested the same clade with the sequence of Moesziomyces parantarcticus CBS: 10005 and M. parantarcticus DMKU-RP39 with low bootstrap value $(<50 \%)$ (Figure 8$)$. The four sequences of Ustilagineous endophytic yeasts (EK20-Y-01, EK20-Y-02, EK20-Y-03, and EK20-Y-04) isolated from water spinach plant tissue nested the same clade with the sequence of $D$. churashimaensis DMKU RP90 and D. churashimaensis YE-162 with $75 \%$ bootstrap value (Figure 8). This phylogenetic tree was unable to clearly determine the species of Moesziomyces and Dirkmeia based on D1/D2 sequence analysis so that additional analysis of the sequence of the other genes was much needed. Multigene analysis conducted by Wang et al. (2015), using 6 other loci areas, namely ITS, SSU,
Rpb1, Rpb2, EF1, and CytB is necessary to determine the identity of Ustilagineous yeasts species.

\section{Future perspective}

Tissue culture is a plant propagation technique that requires an aseptic and controlled environment. The presence of endophytes in tissue culture is often categorized as a contaminant. It generally occurs after transfer to rooting media, which is characterized by the growth of endophytic colonies in the culture medium in direct contact with the explants stems or leaves. However, some endophytes do not grow during in vitro plant culture. It will only appear when the plant culture is transferred to a suitable bacterial or fungal growth medium.

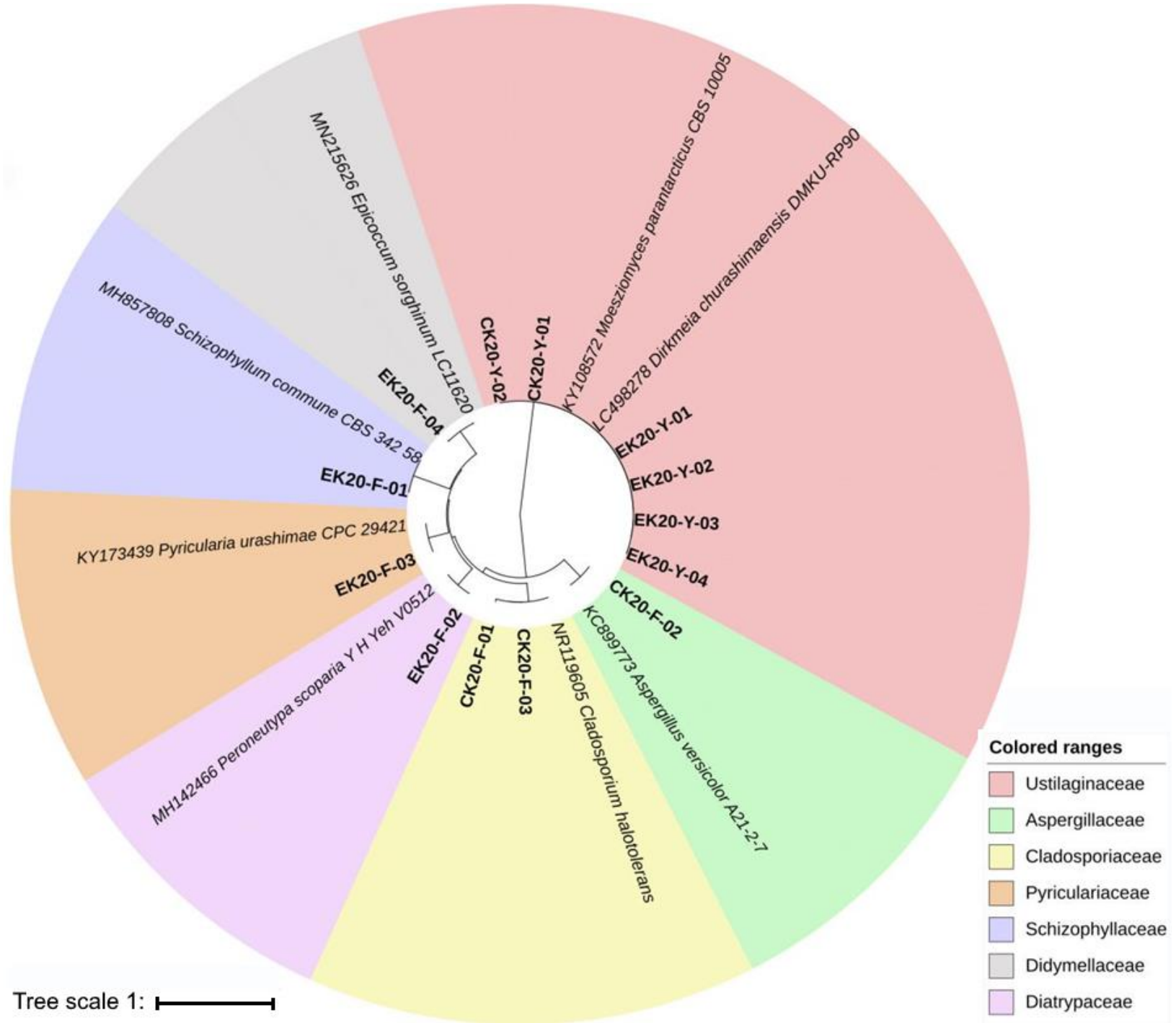

Figure 7. The Neighbor-Joining (NJ) phylogenetic tree of fungal isolates associated with water spinach (Ipomoea aquatica Forssk.) (from tissue and culture media of 'Tetraploid' water spinach) based on D1/D2 region of LSU rDNA and ITS rDNA sequences 
The presence of endophytic microbes in tissue culture media has a negative impact on plant growth if the microbes grow too fast and out of control. This is very detrimental, especially for commercial crops with high production levels so that the elimination of

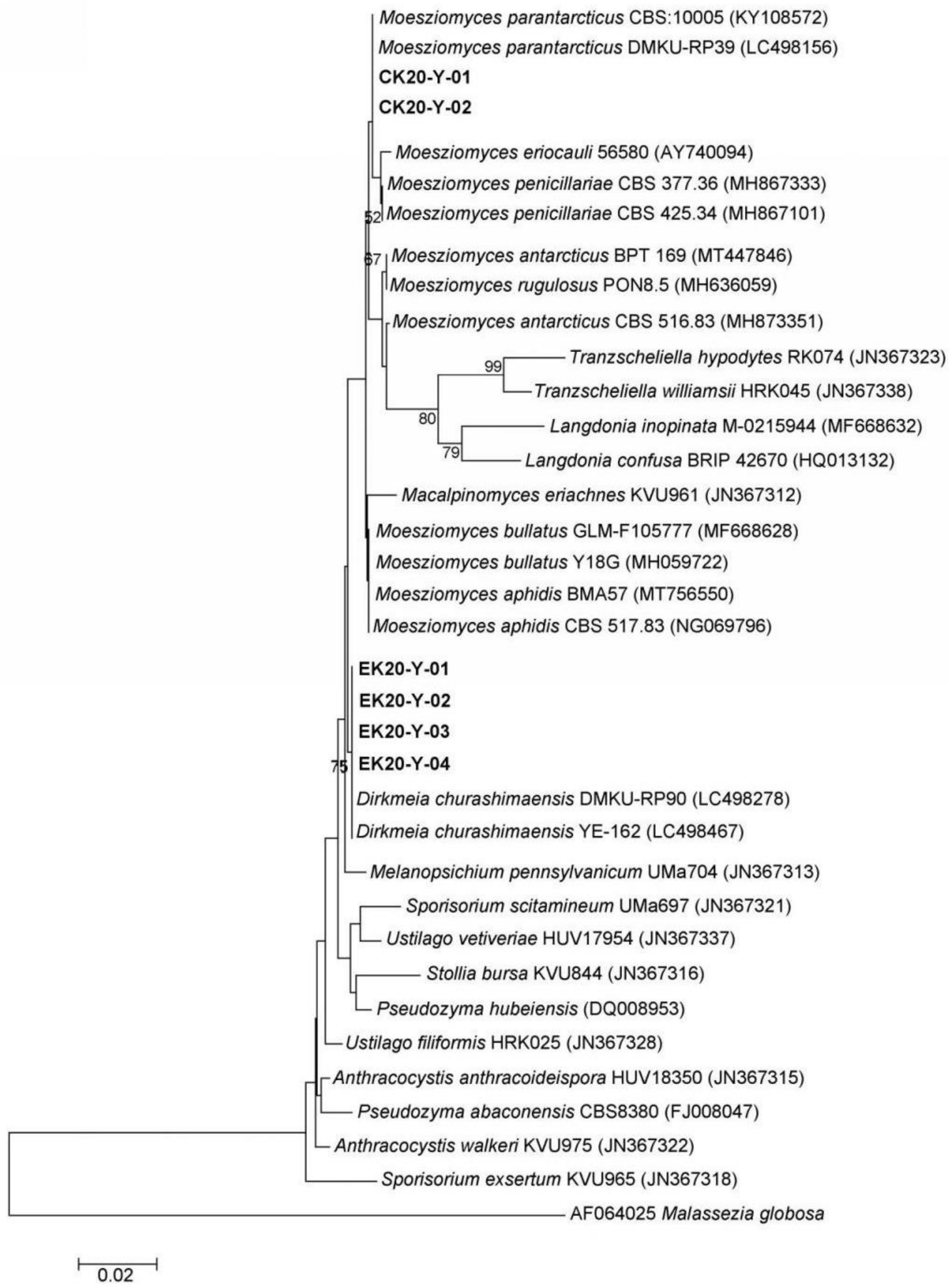

Figure 8. Neighbor-Joining (NJ) tree based on LSU rDNA D1/D2 domain sequences of yeast genera within Ustilaginaceae. Bootstrap values $>50 \%$ are recorded at the nodes (1000 replicates) 
these endophytic contaminants is important. Efforts to eliminate endophytic microbial contamination can be carried out by sterilizing contaminated plants with sterilizing agents such as sodium hypochlorite, mercuric chloride, or silver nitrate. However, the negative impact caused is early browning and senescence in plants or even the growth of resistant bacteria that is too fast and uncontrolled. Maintaining a balance of the total microbial community is more promising for in vitro culture propagation than eliminating these microbes. This can be done by periodic planting of cultures for a certain time on the media supplemented with antibiotics (Quambusch and Winkelmann 2018). Endophytic microbial eradication techniques or methods that are effective in water spinach tissue culture need to be studied to ensure that cultures are free from contaminants originating from endophytic microbes.

\section{CONCLUSION}

A total of 14 isolates have been successfully isolated from water spinach tissue culture media, namely 9 bacterial isolates, 3 fungal isolates, and 2 yeast isolates. As many as eight isolates have been successfully isolated from water spinach plant tissue, namely 4 fungal isolates and 4 yeast isolates. Our study confirmed that only the endophytic yeast from the Ustilaginaceae group (Basidiomycetous yeast) derived from water spinach plant tissue was the same type of contaminant that contaminated the 'Tetraploid' water spinach tissue culture media. Yeast from the Ustilaginaceae (Basidiomycetous yeast) group was also the most dominant microbe that contaminated culture media of water spinach 'Tetraploid' tissue culture.

\section{AUTHOR CONTRIBUTIONS}

All authors have reviewed the final version of the manuscript and approved it for publication. RSR, IRa, and $M$ designed the study; RSR, IRa, $M$, and $Y Y$ performed research and collected the data; $R S R, I R a, M$, $I R i$, and ADP analysed the data and wrote the paper. RSR, IRa, and $\mathrm{M}$ are the main contributor of this manuscript.

\section{ACKNOWLEDGMENTS}

The authors would like to thank Dr. Witjaksono, Researcher at the Research Center for Biology - Indonesian Institute of Sciences (LIPI), who has initiated the idea and guided the implementation of this research. The author also thanks to DIPA Funding of the Research Center for Biology Indonesian Institute of Sciences (LIPI) for the title 'Tetraploid' Induction in Fruit and Vegetable Plants for Increasing Biomass and Provision of Cross broodstock in Triploid Variety Engineering' and for Microbial Biosystematics and Evolution Research Group in 2019 which have funded activities of this research.

\section{REFERENCES}

Abdalla MA, Matasyoh JC (2014) Endophytes as producers of peptides: an overview about the recently discovered peptides from endophytic microbes. Nat Prod Bioprospect 4: 257-270. doi: 10.1007/s13659-014-0038-y

Afzal M, Khan QM, Sessitsch A (2014) Endophytic bacteria: prospects and applications for the phytoremediation of organic pollutants. Chemosphere 117: 232-242. doi: 10.1016/j.chemosphere.2014.06.078

Alexopoulos CJ, Mims CW, Blackwell M (1996) Introductory Mycology. 4th edition. John Wiley \& Sons Inc, New York

Ariyono RQ, Djauhari S, Sulistyowati L (2014) Keanekaragaman jamur endofit daun kangkung darat (Ipomoea reptans Poir.) pada lahan pertanian organik dan konvensional. J HPT 2: 19-28

Arslan M, Imran A, Khan QM, Afzal M (2017) Plant-bacteria partnerships for the remediation of persistent organic pollutants. Environ Sci Pollut Res Int 24: 4322-4336. doi: 10.1007/s11356-015$4935-3$

Biasetto CR, Somensi A, Figueiro FS, de Moraes LAB, Silva GH, Marx Young MC, da Silva Bolzani V, Araújo AR (2019) Diketopiperazines and arylethylamides produced by Schizophyllum commune, an endophytic fungus in Alchornea glandulosa. Eclet Quim J 44: 36-42. doi: 10.26850/1678- 
4618eqj.v44.3.2019.p36-42

Chauhan NM, Gutama AD, Aysa A (2019) Endophytic fungal diversity isolated from different agro-ecosystem of Enset (Ensete ventericosum) in Gedeo zone, SNNPRS, Ethiopia. BMC Microbiol 19: 172. doi: 10.1186/s12866-019-1547-y

Chen J, Zhang L, Jin Q, Su C, Zhao L, Liu X, Kou S, Wang Y, Xiao M (2017) Bioremediation of phenol in soil through using a mobile plant-endophyte system. Chemosphere 182: 194-202. doi: 10.1016/j.chemosphere.2017.05.017

Chitsa H, Mtaita T, Tabarira J (2014) Nutrient content of water spinach (Ipomoea aquatica) under different harvesting stages and preservation methods in Zimbabwe. Int J Biol Chem Sci 8: 854861. doi: 10.4314/ijbcs.v8i3.2

de Errasti A, Novas MV, Carmarán CC (2014) Plant-fungal association in trees: insights into changes in ecological strategies of Peroneutypa scoparia (Diatrypaceae). Flora Morphol Distrib Funct Ecol Plants 209: 704-710. doi: 10.1016/j.flora.2014.07.006

de Melo Pereira GV, Magalhães KT, Lorenzetii ER, Souza TP, Schwan RF (2012) A multiphasic approach for the identification of endophytic bacterial in strawberry fruit and their potential for plant growth promotion. Microb Ecol 63: 405-417. doi: 10.1007/s00248-0119919-3

Dhooghe $\mathrm{E}$, van Laere $\mathrm{K}$, Eeckhaut T, Leus L, van Huylenbroeck J (2011) Mitotic chromosome doubling of plant tissues in vitro. Plant Cell Tiss Organ Cult 104: 359-373. doi: 10.1007/s11240-0109786-5

Felsenstein $J$ (1985) Confidence limits on phylogenies: an approach using the bootstrap. Evolution (NY) 39: 783-791. doi: 10.2307/2408678

Feng NX, Yu J, Zhao HM, Cheng YT, Mo CH, Cai QY, Li YW, Li H, Wong MH (2017) Efficient phytoremediation of organic contaminants in soils using plantendophyte partnerships. Sci Total Environ 583: 352-368. doi: 10.1016/j.scitotenv.2017.01.075

Hapsari RTY, Djauhari S, Cholil A (2014) Keanekaragaman jamur endofit akar kangkung darat (Ipomoea reptans Poir.) pada lahan pertanian organik dan konvensional. J HPT 2: 1-10

Hardoim PR, van Overbeek LS, Berg G, Pirttilä AM, Compant S, Campisano A, Döring M, Sessitsch A (2015) The hidden world within plants: ecological and evolutionary considerations for defining functioning of microbial endophytes. Microbiol Mol Biol Rev 79: 293-320. doi: 10.1128/MMBR.00050-14

Hussain Z, Arslan M, Malik MH, Mohsin M, lqbal S, Afzal M (2018) Integrated perspectives on the use of bacterial endophytes in horizontal flow constructed wetlands for the treatment of liquid textile effluent: Phytoremediation advances in the field. J Environ Manage 224: 387-395. doi: 10.1016/j.jenvman.2018.07.057

Ilyas M, Rahmansyah M, Kanti A (2006) Seri Panduan: Teknik Isolasi Fungi. LIPI Press, Jakarta

Into $\mathrm{P}$, Pontes $\mathrm{A}$, Sampaio JP, Limtong $\mathrm{S}$ (2020) Yeast diversity associated with the phylloplane of corn plants cultivated in Thailand. Microorganisms 8: 80. doi: 10.3390/microorganisms8010080

Jiang $\mathrm{H}$, Dong $\mathrm{H}$, Zhang $\mathrm{G}$, Yu B, Chapman LR, Fields MW (2006) Microbial diversity in water and sediment of Lake Chaka, an athalassohaline lake in northwestern China. Appl Environ Microbiol 72: 38323845. doi: 10.1128/AEM.02869-05

Jumpponen A, Jones KL (2010) Seasonally dynamic fungal communities in the Quercus macrocarpa phyllosphere differ between urban and nonurban environments. New Phytol 186: 496-513. doi: 10.1111/j.1469-8137.2010.03197.x

Katoh K, Rozewicki J, Yamada KD (2019) MAFFT online service: multiple sequence alignment, interactive sequence choice and visualization. Brief Bioinform 20: 1160-1166. doi: 10.1093/bib/bbx108

Kaur M, Chadha P, Kaur S, Kaur A, Kaur R, Yadav AK, Kaur R (2018) Schizophyllum commune induced genotoxic and cytotoxic effects in Spodoptera litura. Sci Rep 8: 4693. doi: 10.1038/s41598-01822919-0

Khunnamwong $P$, Jindamorakot $S$, Limtong $S$ (2018) Endophytic yeast diversity in leaf tissue of rice, corn and sugarcane cultivated in Thailand assessed by a culture-dependent approach. Fungal 
Biol 122: 785-799. doi: 10.1016/j.funbio.2018.04.006

Kimura M (1980) A simple method for estimating evolutionary rates of base substitutions through comparative studies of nucleotide sequences. J Mol Evol 16: 111-120. doi: 10.1007/BF01731581

Kumar S, Stecher G, Tamura K (2016) MEGA7: Molecular evolutionary genetics analysis version 7.0 for bigger datasets. Mol Biol Evol 33: 1870-1874. doi: $10.1093 / \mathrm{molbev} / \mathrm{msw} 054$

Kurtzman CP, Robnett CJ (1998) Identification and phylogeny of ascomycetous yeasts from analysis of nuclear large subunit (26S) ribosomal DNA partial sequences. 73: 331-371. doi: $10.1023 / A: 1001761008817$

Li C, Sarotti AM, Yang B, Turkson J, Cao S (2017) A new N-methoxypyridone from the co-cultivation of Hawaiian endophytic fungi Camporesia sambuci FT1061 and Epicoccum sorghinum FT1062. Molecules 22: 1166. doi: 10.3390/molecules22071166

Li HY, Wei DQ, Shen M, Zhou ZP (2012) Endophytes and their role in phytoremediation. Fungal Divers 54: 11 18. doi: 10.1007/s13225-012-0165-X

Liu Y, Zuo S, Xu L, Zou Y, Song W (2012) Study on diversity of endophytic bacterial communities in seeds of hybrid maize and their parental lines. Arch Microbiol 194: 1001-1012. doi: 10.1007/s00203-012-0836-8

López SMY, Pastorino GN, Franco MEE, Medina R, Lucentini CG, Saparrat MCN, Balatti PA (2018) Microbial endophytes that live within the seeds of two tomato hybrids cultivated in Argentina. Agronomy 8: 136 . doi: 10.3390/agronomy8080136

Mei C, Flinn BS (2010) The use of beneficial microbial endophytes for plant biomass and stress tolerance improvement. Recent Pat Biotechnol 4: 81-95. doi: 10.2174/187220810790069523

Murashige T, Skoog F (1962) A revised medium for rapid growth and bio assays with tobacco tissue cultures. Physiol Plant 15: 473-497. doi: 10.1111/j.13993054.1962.tb08052.x

Nair DN, Padmavathy S (2014) Impact of endophytic microorganisms on plants, environment and humans. Sci World $\mathrm{J}$ 2014: ID 250693. doi: $10.1155 / 2014 / 250693$

Oliveira RC, Davenport KW, Hovde B, Silva D, Chain PSG, Correa B, Rodrigues DF (2017) Draft genome sequence of sorghum grain mold fungus Epicoccum sorghinum, a producer of tenuazonic acid. 5: e01495. doi: 10.1128/genomeA.01495-16

Panaccione DG, Beaulieu WT, Cook D (2014) Bioactive alkaloids in vertically transmitted fungal endophytes. Funct Ecol 28: 299-314. doi: 10.1111/13652435.12076

Quambusch M, Winkelmann T (2018) Bacterial endophytes in plant tissue culture: Mode of action, detection, and control. Methods Mol Biol 1815: 69-88. doi: 10.1007/978-1-4939-8594-4 4

Rahmi P, Witjaksono, Ratnadewi $\mathrm{D}^{-}$(2019) Induksi poliploidi tanaman kangkung (Ipomoea aquatica Forssk.) kultivar Salina in vitro dengan oryzalin. J Biol Indones 15: 1-8. doi: 10.14203/jbi.v15i1.3760

Saad FNM, Lim FJ, Izhar TNT, Odli ZSM (2020) Evaluation of phytoremediation in removing $\mathrm{Pb}, \mathrm{Cd}$ and $\mathrm{Zn}$ from contaminated soil using Ipomoea aquatica and Spinacia oleracea. IOP Conf Ser Earth Environ Sci 476: 012142. doi: 10.1088/1755-1315/476/1/012142

Saitou N, Nei M (1987) The neighbor-joining method: A new method for reconstructing phylogenetic trees. Mol Biol Evol 4: 406-425. doi: 10.1093/oxfordjournals.molbev.a04045 4

Sanger F, Nicklen S, Coulson AR (1977) DNA sequencing with chain-terminating inhibitors. Proc Natl Acad Sci USA 74: 5463-5467. doi: 10.1073/pnas.74.12.5463

Shahzad R, Khan AL, Bilal S, Asaf S, Lee IJ (2018) What is there in seeds? Vertically transmitted endophytic resources for sustainable improvement in plant growth. Front Plant Sci 9: 24. doi: 10.3389/fpls.2018.00024

Shukla ST, Habbu PV, Kulkarni VH, Jagadish KS, Pandey AR, Sutariya VN (2014) Endophytic microbes: A novel source for biologically/ pharmacologically active secondary metabolites. Asian J 
Pharmacol Toxicol 2: 1-16

Song Z, Kennedy PG, Liew FJ, Schilling JS (2016) Fungal endophytes as priority colonizers initiating wood decomposition. Funct Ecol 31: 407-418. doi: 10.1111/1365-2435.12735

Srisuk N, Nutaratat P, Surussawadee J, Limtong $S$ (2019) Yeast communities in sugarcane phylloplane. Microbiol 88: 353-369.

doi: $10.1134 /$ S0026261719030135

Stępniewska Z, Kuzniar A (2013) Endophytic microorganisms - Promising applications in bioremediation of greenhouse gases. Appl Microbiol Biotechnol 97: 95899596. doi: 10.1007/s00253-013-5235-9

Stokholm MS, Wulff EG, Zida EP, Thio IG, Néya JB, Soalla RW, Głazowska SE, Andresen M, Topbjerg HB, Boelt B, Lund OS (2016) DNA barcoding and isolation of vertically transmitted ascomycetes in sorghum from Burkina Faso: Epicoccum sorghinum is dominant in seedlings and appears as a common root pathogen. Microbiol Res 191: 38-50. doi: 10.1016/j.micres.2016.05.004

Strobel G (2018) The emergence of endophytic microbes and their biological promise. J Fungi 4: 57. doi: 10.3390/jof4020057

Suh SO, Blackwell M, Kurtzman CP, Lachance MA (2006) Phylogenetics of Saccharomycetales, the ascomycete yeasts. Mycologia 98: 1006-1017. doi: 10.3852/mycologia.98.6.1006

Suhandono S, Kusumawardhani MK, Aditiawati P (2016) Isolation and molecular identification of endophytic bacteria from rambutan fruits (Nephelium lappaceum L.) cultivar Binjai. Hayati J Biosci 23: 39-44. doi: 10.1016/j.hjb.2016.01.005

Sukmadi RB (2012) Aktivitas fitohormon indole-3-acetic Acid (IAA) dari beberapa isolat bakteri rizosfer dan endofit. J Sains Teknol Indones 14: 221-227. doi: 10.29122/jsti.v14i3.930

Taguiam JD, Evallo E, Bengoa J, Maghirang R, Balendres MA (2020) Pathogenicity of Epicoccum sorghinum towards dragon fruits (Hylocereus species) and in vitro evaluation of chemicals with antifungal activity. J Phytopathol 168: 303-310. doi: 10.1111/jph.12893

Tyc O, Putra R, Gols R, Harvey JA, Garbeva $P(2020)$ The ecological role of bacterial seed endophytes associated with wild cabbage in the United Kingdom. MicrobiologyOpen 9: e00954. doi: 10.1002/mbo3.954

Wang QM, Begerow D, Groenewald M, Liu $X Z$, Theelen B, Bai FY, Boekhout $T$ (2015) Multigene phylogeny and taxonomic revision of yeasts and related fungi in the Ustilaginomycotina. Stud Mycol 81: 55-83. doi: 10.1016/j.simyco.2015.10.004

Wani ZA, Ashraf N, Mohiuddin T, Riyaz-UIHassan S (2015) Plant-endophyte symbiosis, an ecological perspective. Appl Microbiol Biotechnol 99: 29552965. doi: 10.1007/s00253-015-6487-3

Wagner MR, Lundberg DS, Del Rio TG, Tringe SG, Dangl JL, Mitchell-Olds T (2016) Host genotype and age shape the leaf and root microbiomes of a wild perennial plant. Nat Commun 7: 12151. doi: 10.1038/ncomms12151

White TJ, Bruns TD, Lee SB, Taylor JW. (1990) Amplification and direct sequencing of fungal ribosomal RNA genes for phylogenetics. In: Innis MA, Gelfand DH, Sninsky JJ, White TJ (eds). PCR Protocols: A Guide to Methods and Applications. Academic Press, San Diego, pp. 315-322 